\title{
Farmers' Perceptions of Salinity for Ensuring Food Security: Evidence from Coastal Rice-Growing Areas of Bangladesh ${ }^{+}$
}

\author{
Md Aminul Islam 1,*, Lisa Lobry de Bruyn ${ }^{1}$, Nigel W. M. Warwick ${ }^{1}$ and Richard Koech ${ }^{2}$ \\ 1 School of Environmental and Rural Sciences, University Of New England, Armidale 2351, Australia; \\ llobryde@une.edu.au (L.L.d.B.); nwarwick@une.edu.au (N.W.M.W.) \\ 2 School of Health, Medical and Applied Sciences, Central Queensland University, Bundaberg 4670, \\ Australia; r.koech@cqu.edu.au \\ * Correspondence: mislam36@myune.edu.au; Tel.: +61426461464 \\ + Presented at the third International Tropical Agriculture Conference (TROPAG 2019), Brisbane, Australia, \\ 11-13 November 2019.
}

Published: 30 December 2019

\begin{abstract}
Achieving SDGs by 2030 such as "No poverty, zero hunger, good health" is the main priority for policy planning in Bangladesh. Key challenges faced in achieving these goals is encountered in the agricultural sector. This research focused on farmers' perception of salinity and their management strategies, and the implications for policy makers to sustain rice production in the coastal areas of Bangladesh. Household survey data was collected from randomly selected 108 rice farming families from two south-west south-east coastal sub-districts. Semi-structured and pretested questionnaire were used to collect data from the respondents. Majority of the respondents $(89 \%)$ reported that salinity has increased over the last 20 years and they also believe that the current salinity level in their fields are high. In a 2nd field trip 36 farmers from the original sample had soil from their fields measured over two time periods. Farmers' perceived salinity level was then compared with measured field salinity in their rice field. Farmers' perception of soil salinity level in their rice field aligns closely with the measured salinity level in the majority of the cases. It was also observed that farmers' understanding of salinity level is strongly associated with in-field crop condition and soil appearance. $45 \%$ of respondents said their main signals of salinity were from the appearance of the plant and $22 \%$ of farmers also observed the inflorescence becoming white and grain unfilled in rice crops. Results also suggests that early transplanting of rice seedlings during Boro season rice and use of salt tolerant rice varieties having high tolerance during booting stage along with improved irrigation facilities can substantially reduce rice yield loss from salinity effects.
\end{abstract}

Keywords: salinity perception; Boro season rice; food security; coastal areas of Bangladesh

Funding: This work is a part of first author's PhD study and supported by the University of New England International Post Graduate Research Award (UNE IPRA)

Conflicts of Interest: The authors declare no conflict of interest.

(C) 2019 by the authors. Licensee MDPI, Basel, Switzerland. This article is an open access article distributed under the terms and conditions of the Creative Commons Attribution (CC BY) license (http://creativecommons.org/licenses/by/4.0/). 